How to cite this article:

Abdul Razak, M. U. (2020). The disclosure framework of related party transactions in selected ASEAN member states. UUM Journal of Legal Studies, 11(2), 53-76. https://doi.org/10.32890/uumjls.11.2.2020.8011

\title{
THE DISCLOSURE FRAMEWORK OF RELATED PARTY TRANSACTIONS IN SELECTED ASEAN MEMBER STATES
}

\author{
Muhammad Umar Abdul Razak \\ Faculty of Law, Universiti Teknologi MARA, Malaysia \\ PhD Candidate, Ahmad Ibrahim Kuliyyah of Laws, International \\ Islamic University of Malaysia \\ umar0001@uitm.edu.my \\ Received: 9/1/2020 Revised: 27/4/2020 Accepted: 4/6/2020 Published: 31/7/020
}

\begin{abstract}
Related party transaction or RPT is a transaction that could either be harmful or beneficial to the company and minority shareholders. $R P T$ can be considered as an efficient tool for the company or abused by controlling shareholders. Therefore, one of the key factors to address this transaction is through disclosure. This study applied a content analysis method using materials that were largely librarybased including primary and secondary data. Primary data was gathered from relevant theories to explain the application of the legal theories. Meanwhile, secondary data was derived from published materials, such as textbooks, journal articles and online databases. In order to assess these materials, a combination of descriptive, critical and comparative data analysis approaches was employed in this study. This paper aims to understand the underlying applicable legal theories on RPT by analysing and comparing the disclosure framework in Malaysia, Singapore and Thailand that adopt the ASEAN Disclosure Standards ("ADS"). This paper finds that there is a disparity in the disclosure standard among these states despite having ADS in place. This problem calls for a clearer ex-ante approval process in ADS and to consider the model from European Union's Shareholders Amending Directive 2017/828 to improve the disclosure framework in each jurisdiction. In conclusion, ADS has
\end{abstract}


indicated the requisite for conflicted parties to declare and obtain approval from minority shareholders, albeit its procedure and minimal threshold remain unclear.

Keywords: ASEAN, disclosure, minority shareholders, related party transaction.

\section{INTRODUCTION}

Related party transaction or RPT is a transaction between a firm with any related party(s) including directors, material owners, officers, or any person(s) connected to them in any way. The advantages and disadvantages of this transaction have been discussed in the extant literature representing a potential conflict of interest between both parties. Despite the possible drawbacks, it could be beneficial and efficient for a company to undertake this exercise to optimise resources. Expropriation of corporate opportunities arose due to lack of disclosure by the interested director(s). Several studies agreed that companies with less than full disclosure of RPTs tend to carry out abusive RPTs (Utama \& Utama, 2014) and therefore disclosure requirements should be given priority (Chen et al., 2009). As such, the implementation of the disclosure framework could improve the transaction.

The primary focus of this paper is to analyse and compare the disclosure framework in the three (3) selected ASEAN ${ }^{1}$ Member States, namely Malaysia, Singapore and Thailand ("Member States"). Do these Member States have sufficient legal framework in dealing with RPT? As of February 2020, these member states are deemed the largest economies in ASEAN with approximately 2,372 listed companies (total combined) with an aggregate market capitalisation of US\$2.05 trillion (World Exchange Federation, n.d.). They are closely intertwined with each other in terms of society, history and economy. Besides that, these Member States

The Association of Southeast Asian Nations or ASEAN is a regional inter-governmental organisation established in 1967. It comprises ten countries in Southeast Asia to promote inter-governmental cooperation between its member states. Its members are Indonesia, Thailand, Singapore, Malaysia, The Philippines, Myanmar, Vietnam, Brunei, Cambodia and Laos. 
are also signatories to the ASEAN Disclosure Standards (ADS), a set of common standards for disclosure issued by the ASEAN Capital Markets Forum ("ACMF"). The ACMF established in 2014, is a high-level committee under the auspices of ASEAN Finance Ministers to develop "a deep, liquid and integrated regional capital market" (ACMF, n.d.). The ADS aims to promote cross-listing that offers equity and plain debt securities within ASEAN by adopting a single disclosure standard. This paper will focus on the disclosure framework of each jurisdiction when dealing with RPT and compare the framework with ADS. The comparison will serve as a convenient insight to investigate the complexities of corporate governance approaches in each Member State.

\section{LITERATURE REVIEW}

RPT is traditionally viewed as a potentially harmful transaction to the company and its minority shareholders with an adverse impact on a well-functioning capital market. Nonetheless, alternative views are justifying its necessity or benefits. These conflicting views are based on different theories. Hence, understanding the theory and its underlying parameters is useful to determine whether RPT should be regulated, to what extent should it be regulated and if it is to be regulated, how then should the rules be crafted. The theories considered in this scenario are the conflict of interest theory, efficiency hypothesis theory, contingency theory and mandatory/ enabling theory. There are two (2) reasons why these theories are chosen. Firstly, the conflict of interest (Burkart \& Panunzi, 2006; Panda \& Leepsa, 2017) and efficiency hypothesis (Henry et al., 2012) are generally accepted theories to explain the need to have a regulation on RPT. Secondly, due to the inconsistencies and biases in these theories, Pizzo (2013) suggested adopting a pragmatic approach using the contingency theory. This theory has also been employed by scholars in analysing the relationship between sales and earnings in RPT (Marchini et al., 2018a). Besides, the analysis of the mandatory/enabling theory is needed to justify the rationale of having a minimum standard for corporate law if the market fails to protect the shareholders (Ramsay, 1998). Therefore, an analysis of the disclosure concept and its rationale were employed to complement these theories in order to provide a clearer analysis of the need for a stronger disclosure framework for RPT. 


\section{Conflict of Interest Theory}

The conflict of interest theory is a leading theory that considers RPT harmful because it is a potential expropriation tool utilised by controlling shareholders in conflicted transactions. It could be a value-destroying tool if used for managerial opportunism, such as opportunistic earnings management (Marchini et al., 2018b), tunnelling (Johnson et al., 2000), irregular credit terms and excessive loan guarantee (Ariff \& Hashim, 2013). The general principle of this theory is intended to ensure that the directors do not misuse the corporate opportunity to benefit themselves through asset sales and transfer pricing that is advantageous to controlling shareholders at the expense of the minority. The controlling shareholders control the board through the shareholding structure and can influence the company's decision through its board representation. Some regulations compel the conflicted directors to abstain from voting in general meetings. However, conflict of interest per se is not the problem, but rather the undisclosed interests (Salim, 2011). All these problems are consistent with the issues raised by agency theorist where the owners face the risk of asymmetry of interest with that of their agents (Berle \& Means, 1933; Jensen \& Meckling, 1976). Therefore, new RPT rules and regulations were introduced to improve the disclosure regulations. For instance, the disclosure by the interested directors or shareholders subsequently requires board approval, independent directors' opinion, audit committee and external third-party assessment along with the minority shareholders' approval. Thus, certain apparatus is introduced to ensure additional oversight to prevent the directors from expropriating the company at the expense of the minority shareholders. However, these approaches are costly to implement as it increases the cost of monitoring the disclosure with the appointment of the independent board (Anand et al., 2010), external party evaluation and general meeting approval.

\section{Efficiency Transaction Hypothesis}

The efficiency hypothesis argues that RPT is a necessary tool for a business to achieve efficiency. RPT rationally fulfils other economic demands of a company such as procuring detailed skills and knowhow between parties with private information or providing an alternative form of compensation (Gordon et al., 2004). Contract efficiency could lead to the closeness of the related parties with each 
other. Due to this benefit, the related parties enjoy faster access to information among them as opposed to outsiders. For instance, the coordination of activities and feedback between the related parties would be invaluable to have them on board with the directors as a means to obtain quick feedback on operations (Ryngaert \& Thomas, 2007). As for the shareholders, contract efficiency creates an internal capital market for a group of companies when the external market is imperfect. Recent literature has also revealed that RPT is an efficient tool to achieve income smoothing (Shin et al., 2019). Income smoothing involves the manipulation of the time profile of earnings or earnings report to generate an income stream with fewer variables without having to report the increase in earnings in the long run (Fudenberg \& Tirole, 1995). In other words, it involves the manipulation of earnings in the financial report. Therefore, the rules and regulations governing RPT, modifies the no-conflict rule by actually allowing the conflicted transaction to proceed, provided that certain monitoring mechanism is implemented to balance its detrimental effects. Moreover, firms that disclose the value of the RPTs are favourably recognised by the market as efficient RPTs which is represented by an increase in stock price compared to firms that did not disclose (S. Utama et al., 2010). However, empirical evidence was not supportive of the notion to what extent will efficiency ensure that the company be shielded from being expropriated by the controlling shareholders (Pizzo, 2013). Therefore, this gap leads to the following discussion on the contingency perspective in the subsequent sub-section.

\section{Contingency Perspective}

In the sub-sections (a) and (b) mentioned, several gaps and shortcomings were made revealed by the extant literature on the conflict of interest and efficiency theories. For example, some literature argued that empirical evidence demonstrated that RPT is not really bad. Hence, regulations based on conflict of interest theory are usually excessive such as approval by the board and audit committee, which lead to an increase in monitoring cost. In fact, propping (one of the RPT tools) can be used to save a company in distress (Friedman et al., 2003). Although the efficiency hypothesis has been touted as beneficial, the efficiency argument does not appear to be an effective substitute compared to the conflict theory 
and the notion that it is harmless to the shareholders is not supported by sufficient empirical evidence (Pizzo, 2013). Consequently, the efficiency hypothesis failed to cope with different existing situations in other jurisdictions, especially in many Asian countries.

Therefore, a shift in the RPT regulation approaches was proposed by examining the causes and consequences of RPT in light of the influences exercised by the organisational context (Aguilera et al., 2008). The shift was put forth because corporate governance is prone to vary depending on internal and external resources, market, sectoral, regulatory or institutional environments. Concerning corporate governance, this theory argues that the universal best practices should be rejected due to its varying effectiveness based on internal or external contingent factors. For example, in certain jurisdictions within Asia, both the mentioned theories are unable to address the problems as there is a higher concentration of ownership in a company (as opposed to dispersed ownership in American or European jurisdiction). Moreover, there is no evidence that these theories can possibly co-exist. Hence, from a corporate governance perspective, contingency theory could act as the determining factor in explaining that "one-size-fits-all" framework does not apply to everyone. Instead, the effectiveness of any corporate governance framework varies from one region to another. RPT regulations in EU may appear ideal because it was intended to address the issue of asymmetry of interests between the managers and the company due to the dispersed ownership, but it could be chimerical in Asian jurisdictions. For e.g. appointment of independent directors as suggested in the Cadbury Report is to improve the disclosure level in public companies (Cadbury, 1992). However, independent directors in Asia do not function in the same manner as practised in the US/UK model. This dissimilarity is due to the tendency of independent directors who tend to work cooperatively together with the controlling shareholders in most Asian corporations (Aronson, 2017), rather than providing the checks and balances. Furthermore, the excessiveness in implementing RPT regulations could influence the reporting entity to hide the truth regarding their relationship with the related-parties, and thus, raise the monitoring cost if these regulations are not guided with a strengthened audit rule (Pizzo, 2013). Therefore, the drafters of the RPT rules and regulations may incorporate the best universal practices by considering the potential 
diversity of governance mechanism to best suit local needs, which deals with essential contingencies.

\section{Mandatory/Enabling Theory}

In addition to the contingency theory argument, this theory was first introduced by Coffee (1989). The theory stated that the court should recognise the mandatory minimum standards of corporate law, which includes the duty of good faith, while protection against unconscionable provisions theory provides a basis to understand the need of having an enabling corporate governance framework. According to Keay (2007), there are two types of laws to govern companies, namely the mandatory and enabling. Mandatory law which is also referred to as "immutable rules" cannot be modified by the parties nor subjected to negotiation by the contracting parties. Meanwhile, the "enabling rules" or default laws are also sometimes referred to as "gap-filling", "facilitative", "standby", "fall back" or "backstop". Enabling rules can be varied, where it permits companies and others to modify or opt-out of the application of those laws through contract.

Thus, this theory fills the gap in the void that was left by the conflict and efficiency scholars. This theory addresses the concern regarding the overarching rules that are imposed in corporate law. The importance of mandatory rules is that it provides a platform for the parties to enter into a contract by facilitating liberty to contract and aiding the corporate actors to be bound by those terms. Having a standard form of contract allows for the simplification of contracting among the parties whereby they can specifically work on those elements in the relationship that deviate from the standard terms.

The phrase "mandatory" is referred to as legally-mandated with potential penalties to those who fail to adhere to the legal rules. When the law is mandatory, the judges have little role in the lawmaking process because only the legislature is entrusted to make the law. For example, the mandatory disclosure rule requires the conflicted managers to declare their interest in a proposed transaction involving them. In contrast, an enabling law makes most of the statutory provisions optional where it allows parties to reallocate control rights (Pistor et al., 2003). 
The terms "voluntary" or"enabling" denotes afirm's choice to embrace corporate governance practices or standards where a mandatory legal requirement is absent. The contracting parties are allowed to exercise their discretion subject to a "review" by other self-interested actors (Easterbrook \& Fischel, 1989). This theory implies that attempts to harmonise a different set of corporate codes in enabling the choices of shareholders are welcomed based on transparency and information (Gelter, 2017). For instance, the enabling rules are adopted in nonmandatory code of corporate governance when issues in corporate governance cannot be addressed by mandatory law alone due to the complexities. Therefore, voluntary self-regulation is used as a supplement to mandatory law (Salim, 2017). Firms and corporations are at liberty to adopt any prevailing codes to suit their business requirements. This statement is especially true when the regulator issues enabling rules that are aimed to increase transparency in RPT and to reduce the tendency of a conflict of interest therein (Bava \& Di Trana, 2016). As such, disclosure is known as an effective tool in corporate governance since it is present in many non-mandatory guidelines or rules issued by regulators all over the world. Next, in the light of the discussion of the four theories mentioned, Part III discusses disclosure as an effective governance tool in moderating the effects of RPT.

\section{DISCLOSURE AS A GOVERNANCE TOOL}

All the four theories discussed earlier do have something in common, which is the need for an effective disclosure in RPT. Disclosure is one of the methods employed to monitor the manager's behaviour to reduce the problems of moral hazard at the expense of the agency and as a provision of information (Abdul Rahman \& Salim, 2010). Notwithstanding that, a balance must be struck between the need for disclosure, disproportionate cost, the uselessness of much of the information and the need to maintain confidentiality in certain circumstances (Farrar, 2008). The disclosure must be treated with care so as not to cause unexpected disclosures like trade secrets or confidential information. The disclosure framework emphasises and enforces equal access to information in order to encourage shareholders to access, analyse and trade on corporate information (North, 2009). Hence, this framework allows minority shareholders 
to make fully-informed decisions to either approve or reject based on the board's disclosure.

In general, there are two broad approaches that have been adopted in dealing with RPT, namely ex-ante approval and ex-post liabilities (Kamin \& Rachlinski, 1995). Prior approval is required by virtue of no-conflict rule, which is well developed in the common law system. It is a generally accepted rule that directors should not put themselves in a position which could lead to a conflict of interests. It was held in Aberdeen Railway Co v Blaikie Brothers (1854) 1 Macq 461 that a director was in breach of his fiduciary duty when the company had entered into a contract to purchase equipment with another partnership, whereas the chairman of the company and the managing partner of the latter was of the same person. As the director did not disclose his interest in the contract, the contract was declared void.

On the other hand, the ex-post principles-based approach involves litigation as the court acts against predefined duties and liabilities. This approach is widely adopted by many Commonwealth Asian countries, including Malaysia and Singapore, where transactions are reviewed by courts based on predefined standards of conduct (Pacces, 2011). This approach regulates the directors' duties by finding them liable for improperly approving the RPT as a breach of duty of care. Being the key personnel conferred with vast powers in a company's articles, directors are expected to exercise bona fide in the best interest of the company and not for any collateral purpose. Thus, directors who approve self-dealing transactions may incur liability. If there was an element of conflict of interest, the director's argument that he acted in good faith is very unlikely to be accepted by the court as was decided in The Bell Group Ltd (in Liq) $v$ Westpac Banking Group (No 9) [2008] WASC 239. Similar repercussions have been observed in Malaysia, Singapore and Thailand, where directors or controlling shareholders who knowingly approve any connected transactions in contravention of the law will be held liable and punished with imprisonment and fine. However, this study will only emphasise on the ex-ante approval process, which is discussed in Part IV below. 


\section{LEGAL ANALYSIS ON RELATED PARTY TRANSACTION DISCLOSURE FRAMEWORK IN SELECTED ASEAN MEMBER STATES}

Due to the significance of disclosure to address issues related to RPT, Table 1 lists the disclosure legal framework adopted in Malaysia, Singapore and Thailand. The analysis is divided into three parts, namely (a) threshold, (b) the process and (c) content.

\section{Disclosure Threshold}

Malaysia: Bursa Malaysia's Listing Requirements ("Listing Requirements") require a certain percentage of threshold approval in a general meeting. There are three (3) materiality thresholds that warrant disclosure to Bursa Malaysia (Bursa) and the shareholders (Table 1):

Table 1: Disclosure Threshold under the Listing Requirements

\begin{tabular}{lccc}
\hline \multicolumn{1}{c}{ Threshold } & Announcement & Shareholders & $\begin{array}{c}\text { Third-Party } \\
\text { Opinion }\end{array}$ \\
\hline $\begin{array}{l}\text { If the value of the } \\
\text { transaction is } 0.25 \% \\
\text { or more, }\end{array}$ & Bursa & - & $\begin{array}{c}\text { Audit } \\
\text { Committee }\end{array}$ \\
$\begin{array}{l}\text { If the value exceeds } \\
5 \% \text { : }\end{array}$ & Bursa & $\begin{array}{c}\text { Circulars \& } \\
\text { Approval from the } \\
\text { general meeting }\end{array}$ & $\begin{array}{c}\text { Independent } \\
\text { adviser }\end{array}$ \\
$\begin{array}{l}\text { If the value is } 25 \% \\
\text { or more: }\end{array}$ & Bursa & $\begin{array}{c}\text { Circulars \& } \\
\text { Approval from the } \\
\text { general meeting }\end{array}$ & Main adviser \\
\hline
\end{tabular}

Singapore: Under the Singapore Exchange's Listing Manual ("Listing Manual"), listed company must announce to the Singapore Exchange ("SGX") and obtain shareholders' approval if the transaction reaches two (2) thresholds as follows: 
Table 2: Disclosure Threshold under the Listing Manual

\begin{tabular}{|c|c|c|c|}
\hline Threshold & Announcement & Shareholders & $\begin{array}{l}\text { Third-Party } \\
\text { Opinion }\end{array}$ \\
\hline $\begin{array}{l}3 \% \text { of the listed } \\
\text { company's net tangible } \\
\text { asset (NTA) or } \\
\$ 100,000 \text { or more; }\end{array}$ & SGX & - & - \\
\hline $\begin{array}{l}5 \% \text { of the listed } \\
\text { company's NTA. }\end{array}$ & SGX & $\begin{array}{l}\text { Circulars \& } \\
\text { Approval from } \\
\text { the general } \\
\text { meeting }\end{array}$ & $\begin{array}{l}\text { Independent } \\
\text { financial } \\
\text { adviser }\end{array}$ \\
\hline $\begin{array}{l}\text { Sale of property unit to } \\
\text { an interested person }\end{array}$ & SGX & $\begin{array}{l}\text { Circulars \& } \\
\text { Approval from } \\
\text { the general } \\
\text { meeting }\end{array}$ & $\begin{array}{l}\text { Independent } \\
\text { financial } \\
\text { adviser }\end{array}$ \\
\hline
\end{tabular}

Thailand: Thailand regulations distinguish the type of connected transactions and practise a different level of approval threshold. Certain categories from the connected transactions require approval from the Stock Exchange of Thailand ("SET"), the board of directors or shareholders.

Usually, based on the net tangible assets ("NTA"), the threshold requiring approval falls between $0.03 \%$ and $3 \%$. For example, a 'transaction related to asset and service' with the value of less than 1 million baht or less than $0.03 \%$ from the NTA does not require any sort of disclosure or approval from anyone. However, if the value is more than 20 million baht, the company is obliged to disclose to SET and to obtain approvals from the directors and three-fourths of the shareholders. 
Table 3: Disclosure Threshold in Thailand

\begin{tabular}{lllllc}
\hline $\begin{array}{c}\text { Transaction } \\
\text { size }\end{array}$ & \multicolumn{1}{c}{ Threshold } & Announcement & Board & Shareholders \\
\hline Small & $\begin{array}{l}\mathrm{x} \leq 1 \text { million } \\
\text { baht }\end{array}$ & $\begin{array}{l}\mathrm{x} \leq 0.03 \% \\
\mathrm{NTA}\end{array}$ & - & Approval & - \\
Medium & $\begin{array}{l}1 \text { million } \\
\text { baht }<\mathrm{x}<20 \\
\text { million baht }\end{array}$ & $\begin{array}{l}0.03 \% \mathrm{NTA}< \\
\mathrm{x}<3 \% \mathrm{NTA}\end{array}$ & SET & Approval & Approval \\
& $\begin{array}{l}\mathrm{X} \geq 2 \\
\text { million baht }\end{array}$ & $\mathrm{X} \geq 3 \%$ NTA & SET & Approval & Approval \\
Large & & & & \\
& & & & & \\
\hline
\end{tabular}

\section{Ex-ante Approval Process}

Malaysia: In Malaysia, the disclosure of RPT is governed by the Companies Act 2016, Capital Markets and Services Act 2007 and the Listing Requirements ${ }^{2}$. Under common law, when a director enters into a transaction with the company, the director is in breach of the no-conflict rule. In the case of Transvaal Lands Co $v$ New Belgium (Transvaal) Lands and Development Co [1914] 2 Ch 488, the court held the acquisition of a company was invalid because the directors; Samuel and Harvey had a conflict of interest in the target company by virtue of their multiple directorships and family relationship. This conflict was not disclosed to the board. By virtue of Section 221 of the Companies Act 2016, it is mandatory for a director who is in any way, as soon as practicable upon realising his interest is in conflict with the company, whether directly or indirectly, disclose the nature of his interest at the board meeting by way of general notice. The audit committee is also obliged to evaluate and report to the board regarding any RPT and conflict of interest that may emanate within the listed company or group including any transactions, procedure or acts that could question the management integrity. ${ }^{3}$ Moreover, the particular director is not allowed to vote in the contract where

2 Only applicable to corporations listed on the stock exchange.

3 Para 15.12, Listing Requirements. 
his interest is in conflict with that of the company. ${ }^{4}$ Consequently, failure to disclose interest will render the contract void at the option of the company. A similar provision is found in Section 151 and 317 of the Capital Market and Services Act 2007, where any member or directors having a direct or indirect interest to the corporation shall disclose such interest to the corporation.

Furthermore, Para 10.08 (8) of the Listing Requirements states that an interested director in RPT must inform the relevant board of directors approving the transaction, the details of the extent of his interest, including all matters relating to the proposed RPT that he is aware or should reasonably be aware of. It must first be accepted by a resolution in the general meeting if such arrangement or transaction will benefit that director or substantial shareholder. Besides that, they are also refrained from voting on the resolution to approve the RPT in the general meeting. It is, however, interesting to note that there is no law or regulations prohibiting the interested director or member(s) from attending the meeting. Hence, their presence could intimidate and influence the voting decision of the minority shareholders during the general meeting.

Singapore: Generally, the directors are required to disclose their interest that is in conflict with the company as required under Section 156(1) of the Singaporean Companies Act (Chapter 50). As such, it compels the interested director to disclose the nature of his interest if his interest is in "any way, whether directly or indirectly", conflicted in a transaction with the company. As was decided in the case of Yeo Geok Seng v Public Prosecutor [2000] 1 SLR 195, the director's interest need not be personal but is sufficient as long as he is directly or indirectly interested in the contract, he is deemed to be "interested" which warrants a disclosure to the board. However, the disclosure obligation does not apply where the director's interest consists only of his being a member or creditor of a corporation which is interested in a transaction. The disclosure is to be made in the form of a general notice to other directors to cover all future transactions between specified companies.

4 Section 222 of the Act provides that a director, who is in any way whether directly or not, interested in a contract entered into with the company, shall not participate in the discussion when the contract is being considered and shall not vote on the contract or proposed contract. However, it is a good practice that the interested director leaves the meeting and to not participate in the deliberation process. Nevertheless, the law does not prohibit his attendance in the meeting. 
Part 918 of Chapter 9 of the SGX Listing Manual provides that if the transaction reaches a certain threshold, shareholders' approval must be obtained before entering the transaction or if it is expressed to be conditional upon such approval, before the completion of the transaction.

Thailand: Connected transactions refer to any transactions between a listed company with its connected personnel. The Thai Civil and Commercial Code B.E. 2468 (1925) prohibits a shareholder from voting in a resolution of which he has a conflict of interest. As for the disclosure and approval process, the concerned approval depends on the categories and transaction size. There are five types of connected transactions that require approval including ordinary business transactions, ordinary business support transactions, on tenancy not exceeding three (3) years, transactions involving assets or services and financial assistance. Similar to Malaysia and Singapore, any connected transaction requires approval from the board as well as the shareholders. For example, under the financial assistance transaction where the value is less than 100 million baht or $3 \%$ of NTA value, the company must disclose the transaction to SET and seek the board's approval. However, for a transaction exceeding this threshold, the company must convene a general meeting to acquire the shareholders' approval by giving at least fourteen (14) days notice to the shareholders and to SET by disclosing certain material information such as the identity of the connected persons, the company's business and its operation, any recent inter-transactions and a summary of financial statements for the past three years. ${ }^{5}$ Hence, at least three-fourths (3/4) of the shareholders (excluding interested shareholders) must approve the transaction.

\section{Content of Disclosure}

Malaysia: If the proposed RPT has reached the minimum threshold, the listed company must first announce to Bursa, then forward the draft circular to the shareholders and Bursa. The announcement must contain relevant information regarding the nature and names of parties involved. It must also provide a statement on whether the directors, major shareholders or persons connected with a director(s) or major shareholder(s), have any direct or indirect interest in the transaction, along with the nature and extent of their interests. If

Clause 20 of Thailand's Disclosure of Information and Other Acts of

Listed Companies Concerning the Connected Transactions, 2003. 
RPT threshold is $5 \%$ and above, a third party such as an independent adviser $^{6}$ is required to provide their evaluation as to whether the transaction is fair and reasonable for the shareholders and whether the transaction is prejudicial to the minority shareholders.

Singapore: Under Section 156 of Singaporean Companies Act (Chapter 50), the following must be disclosed:

(1) The nature of a director's interest (whether direct or indirect, and including an interest of a member of director's family in any contract or proposed contract with the company;

(2) The nature, character and extent of any conflict that might arise by virtue of a director holding any office;

(3) The nature, character and extent of any conflict that might arise by virtue of a director owning any property.

Meanwhile, under Chapter 9 of the SGX's Listing Manual, subject to certain exceptions, all other interested person transaction must either be disclosed immediately or approved by the shareholders. Such transactions must be announced if it reaches a certain threshold value. Para 904(5) states that an interested person transaction is defined as a transaction between an entity at risk and an interested person. In general, the announcement must contain the following: the information on the parties involved in the transaction, the rationale and benefit to the entity at risk. The announcement should also comprise of a statement by the audit committee on whether it is on commercial terms and is not harmful to the listed company or its minority shareholders. Alternatively, the audit committee will form its opinion based on an independent financial adviser. If the transaction requires shareholders' approval, then an independent financial adviser should form an opinion whether the transaction is entered based on commercial terms and whether it is prejudicial to the minority shareholders. ${ }^{7}$ One of the primary reasons for requiring independent advice is based on the independent financial adviser giving an objective and professional analysis of the RPT, which will enable the board to evaluate the transaction and give its recommendation to the shareholders (Wan, 2012). Apart from

6 Para 10.08 (3) \& (4) of Bursa Malaysia Listing Requirements: For a transaction of $5 \%$ and above, an independent adviser will be appointed, meanwhile if it is $25 \%$ and above, a main adviser will be appointed.

7 Rule 921 (4) of SGX Rules. 
the prompt disclosure to the regulator, SGX Listing Manual also requires the company to state the interested person transaction in its annual report together with the aggregate value of all transactions during the financial year under review. ${ }^{8}$

Thailand: The board must also prepare a report and disclose to SET the relevant information regarding the connected transaction including the date of the decision made to enter into such transaction, general explanation regarding the asset concerned, the name of the parties involved, parameters of the transaction and most importantly, the board's opinion on the reasonableness and benefits of the transaction to the company. Additionally, the audit committee must also prepare an opinion which is different from the board. ${ }^{9}$ Furthermore, SET requires the opinion of the independent financial adviser (IFA) regarding the rationality and benefits of the transaction to the company, the fairness of the transaction and the reasoning whether the shareholders should approve or reject the transaction (Notification of the Stock Exchange of Thailand: Opinion of Financial Advisors Concerning Connected Transaction, 2003). A similar disclosure is also stated in the notice to the shareholders before convening the general meeting to obtain at least three-fourth (3/4) of the shareholders' approval of the transaction.

\section{ANALYSIS OF THE ASEAN DISCLOSURE STANDARDS}

In 2003, ten leaders of the ASEAN reached an 'ASEAN Concord' to establish the so-called "ASEAN Economic Community" ("AEC") which came into effect in 2015. AEC had introduced the ASEAN Economic Blueprint 2015 and the revised AEC Blueprint 2025 with the primary aim, among others, to achieve a highly integrative and cohesive economy and a "Global Asian" (ASEAM Secretariat, 2015). ADS is primarily developed for an offering of plain debt or equity across ASEAN countries as it aims to harmonise the disclosure standards for prospectuses used in connection with initial public offerings (IPOs). ${ }^{10}$ This standard allows a single and

\footnotetext{
8 Rule 907 of SGX Rules.

9 Part 5 of Disclosure of Information and Other Acts of Listed Companies Concerning the Connected Transaction, 2003 (Bor.Jor./Por/22-01)

10 Adopted by Malaysia, Singapore and Thailand as the participating
} 
common prospectus to be used in multiple listings across various jurisdictions in the ASEAN. The standard has been benchmarked against the International Organization of Securities Commissions (IOSCO) International Equity Disclosure Standards 1998. In Part VII (B) of ADS, there is a provision of RPT disclosure that entails the requirement to disclose any information regarding issuers who intend to do dual listing in other member states. Having compared the disclosure framework from the mentioned selected Member States with the ADS, the following are our findings.

The ADS does not lay down a specific requirement for the conflicted parties to declare to the corporation of their interest in RPT and to obtain the approval from the disinterested parties (i.e. minority shareholders). In fact, it only requires a very minimal disclosure such as disclosing the identity of the related parties but it does not provide for any rules to disclose through the ex-ante approval process nor prescribe any ex-post implications.

Should RPT be regulated, and to what extent is the scope of the regulation? This study postulates that RPT should be regulated to avoid minority shareholders from being expropriated by controlling shareholders. This is because controlling shareholders may act in their interest by utilising the minority's wealth (funds) (Arshad, 2015). However, the parameter of such regulations varies among jurisdictions due to different legal systems. In essence, there are no universal standards that can be applied to each ASEAN member states. In brief, this study revealed that every member state has a minimal disclosure standard as was seen in their respective company law and listing regulations, which were drafted to balance the risk of conflict of interest in RPT by considering the efficiency benefits of the transaction. All member states require the interested parties to disclose their interest to the board and obtain the shareholders' approval.

Furthermore, this study also identified that the selected member states have gone above and beyond the minimal requirements in

ADS by imposing even stricter regulations (apart from the disclosure of interest) such as the necessity to obtain approval from the board

Member States. 
and also from the minority shareholders. On the other hand, if the proposed RPT reaches a higher threshold, a third independent opinion is sought to moderate the associated risks by providing their opinion on whether such transaction is done within arm's length and does not jeopardise the interest of the minority shareholders. This is exemplary because the board of directors are required to act in the best interest of the company and are obliged by the statute to seek third party opinion on their business judgements when necessary. It is because each jurisdiction considers the risk of RPT that could jeopardise the interest of the minority shareholders. Therefore, this study recommends for ADS to re-examine the inclusion of a clearer legal framework on the ex-ante approval process.

The challenge, nonetheless, is on how to enforce a rule that has no binding effect on the member states. Hence, it has been argued that ADS is suffering from a lack of success due to (among others), fragmentation in the interpretation, monitoring, and enforcement across the member states (Wan, 2017). ASEAN's attempt to emulate the European Union model lacks clarity in many areas. For example, there is neither principle of primacy or supremacy of ASEAN law over national law nor a supra-national court to enforce any laws or policies nor any enforcement agency to do so. In addition, the EU has its own legal framework governing the relations among its member states, including a specific body to pass the law and the enforcement agency. ASEAN member states, on the other hand, have little of them in its framework. For example, Article 3 of the ASEAN Charter recognises the body as a legal personality (ASEAN, 2007) but there is no legislative body or organisation that can enforce any regulations or standards. The ADS is just a mere persuasion and is not even binding. Besides, it appears that all the member states still adopt the "ASEAN Way" of resolving disputes which is a less formalised mechanism (Leviter, 2010). The establishment of the principle of supremacy which is the bulwark of the regional rule of law in the EU is clearly precluded in ASEAN because the ASEAN Charter is silent on this (Deinla, 2017). In fact, the watered-down version of the ASEAN Charter which was adopted in 2007 was inclined towards retaining the inter-governmental character of ASEAN and dispelled any suggestion to create a supra-national body (Ahmad, 2016).

In this regard, ASEAN should at least consider studying the European Union's harmonisation law on RPT and the Shareholder 
Rights Amending Directive 2017/828 (“SRAD”) which was passed on 17 May 2017 to address the concerns of insufficiency of engagement between shareholders and lack of protection for the minority shareholders in RPT. Article 9c of SRAD stipulates that every significant transaction with related parties must be approved by the shareholders (Directive (EU) 2017/828, 2017). Furthermore, a significant transaction must be defined where the companies are required to disclose the impact of RPT and any risk associated with it to the shareholders. SRAD also requires the member states to publicly announce the material transactions with the related parties at the time of the conclusion of the transaction. Such announcement must also contain certain information such as the nature of the related party relationship, the identity of the related party, and any other information that is necessary to determine whether or not the transaction is fair or otherwise. Furthermore, it also provides for public announcement and accompanied by an assessment report which determines whether the transaction is fair and reasonable to the company and its shareholders, including the minority.

This paper, however, does not intend to indulge further on the comparative discussion of the ASEAN and European Union legal framework as the scope of this paper is to analyse the disclosure framework in the selected ASEAN member states.

\section{CONCLUSION}

In conclusion, RPT is deemed harmful and at the same time beneficial to a company due to many reasons. The extant of literature agreed that RPT is one way to expropriate the minority shareholders. However, it must be balanced using an effective disclosure framework to ensure that the rights of minority shareholders are not jeopardised. This study highlighted that the selected member states in ASEAN have their respective ex-ante disclosure process in place to offset the risk of RPT; however, these processes are not standardised. Even though ASEAN has ADS to promote cross-listing capital market among the member states, it may not be clear or, has the sufficient legal framework or incentives to encourage companies to implement it. Admittedly, it is challenging to implement harmonisation of law at a regional level due to unique features that are inherent in 
each jurisdiction. Lack of enforcement or a clear policy could be the possible cause. Therefore, it is recommended that ASEAN policymakers consider the idea of having a standardised legal framework that could incentivise the harmonisation of the legal framework in ASEAN by way of emulating their European counterparts' experience. Although ASEAN lacks the legal structure and enforcement in the capital market area especially on RPT, it is hoped that this paper will prompt interest and discussion on the need for stronger rules, regulations or soft-laws on RPT at the regional level.

\section{ACKNOWLEDGEMENTS}

This research received no specific grant from any funding agency.

\section{REFERENCES}

Abdul Rahman, R., \& Salim, M. R. (2010). Transparency and disclosure. In Corporate Governance in Malaysia: Theory, Law and Context. Sweet \& Maxwell Asia.

ACMF. (n.d.). About ACMF. ASEAN Capital Market Forum. Retrieved from https://www.theacmf.org/about/about-acmf.

Aguilera, R. V., Filatotchev, I., Gospel, H., \& Jackson, G. (2008). An organizational approach to comparative corporate governance: Costs, contingencies, and complementarities. Organization Science, 19 (May-June), 475-492. https://doi.org/10.2139/ ssrn. 955043

Ahmad, A. R. (2016). The ASEAN charter: An analysis. UUM Journal of Legal Studies, 7, 83-94.

Anand, A., Milne, F., \& Purda, L. (2010). Monitoring to reduce agency costs: Examining the behavior of independent and nonindependent boards (No. 1243).

Ariff, A. M., \& Hashim, H. A. (2013). The breadth and depth of related party transactions disclosures. International Journal of Trade, Economics and Finance, 4(6), 388-392. https://doi. org/10.7763/IJTEF.2013.V4.323

Aronson, B. (2017). Case studies of independent directors in Asia. In D. W. Puchniak, H. Baum., \& L. Nottage (Eds.), Independent directors in Asia: A historical, contextual and comparative approach. Cambridge University Press. 
Arshad, R. (2015). Does ownership structure matter for publicly listed companies performance in Malaysia? UUM Journal of Legal Studies, 6, 88-96.

ASEAM Secretariat. (2015). ASEAN Economic Community Blueprint 2025.

ASEAN. (2007). The ASEAN Charter. In ASEAN Secretariat. https://doi.org/10.1142/9789813221147_0005

Bava, F., \& Di Trana, M. G. (2016). Disclosure on related party transactions: Evidence from Italian listed companies. Accounting, Economics and Law, 6(2), 119-150. https://doi. org/10.1515/ael-2014-0020

Berle, A. A., \& Means, G. C. (1933). The modern corporation and private property. MacMillan.

Burkart, M., \& Panunzi, F. (2006). Agency conflicts, ownership concentration, and legal shareholder protection. Journal of Financial Intermediation, 15(1), 1-31. https://doi. org/10.1016/j.jfi.2004.12.004

Cadbury, A. (1992). Report of the Committee on the Financial Aspects of Corporate Governance.

Chen, Y., Chen, C. H., \& Chen, W. (2009). The impact of related party transactions on the operational performance of listed companies in China. Journal of Economic Policy Reform, 12(4), 285-297.

Coffee, J. C. (1989). The mandatory / enabling balance in corporate law : An essay on the judicial role author. Columbia Business Law Review, 89(7), 1618-1691.

Deinla, I. (2017). ASEAN community and building the law regime in ASEAN. In The Development of the Rule of Law in ASEAN (Vol. 13, Issue 2007). https://doi.org/10.1017/9781108147934.006

Directive (EU) 2017/828, Pub. L. No. Directive (EU) 2017/828, 20171 (2017).

Easterbrook, F. H., \& Fischel, D. R. (1989). The corporate contract. Columbia Law Review, 89(7), 1416-1448. https://doi. org/10.2307/1122807

Farrar, J. (2008). Corporate governance theories, principles and practice (3rd ed.). Oxford University Press.

Friedman, E., Johnson, S., \& Mitton, T. (2003). Propping and tunneling. Journal of Comparative Economics, 31(4), 732750. https://doi.org/10.1016/j.jce.2003.08.004

Fudenberg, D., \& Tirole, J. (1995). A theory of income and dividend smoothing based on incumbency rents. Journal of Political Economy, 103(1), 75-93. https://doi.org/10.1086/261976 
Gelter, M. (2017). EU company law harmonization between convergence and varieties of capitalism. In Research Handbook on the History of Corporate and Company Law (355/2017, Issue June).

Gordon, E. A., Henry, E., \& Palia, D. (2004). Related party transactions and corporate governance. In M. Hirschey, K. John, \& A. K. Makhija (Eds.), Corporate Governance (Advances in Financial Economics) (Vol. 9, pp. 1-27). Emerald Group Publishing Limited.

Henry, E., Gordon, E., Reed, B., \& Louwers, T. (2012). The role of related party transactions in fraudulent financial reporting. Journal of Forensic \& Investigative Accounting, 4(1), 186213. https://doi.org/10.2139/ssrn.993532

Jensen, M. C., \& Meckling, W. H. (1976). Theory of the firm: Managerial behavior, agency costs and ownership structure. Journal of Financial Economics, 3(4), 305-360. https://doi. org/10.1016/0304-405X(76)90026-X

Johnson, S., La Porta, R., Lopez-De-Silanes, F., \& Shleifer, A. (2000). Tunnelling. American Economic Review, 90(2), 22-27. https://doi.org/10.2307/117185

Kamin, K. A., \& Rachlinski, J. J. (1995). Ex Post $\neq$ Ex Ante: Determining liability in hindsight. Law and Human Behaviour, 19(1), 89-104.

Keay, A. (2007). Company directors' responsibilities to creditors. Taylor \& Francis. https://doi.org/10.4324/9780203945438

Leviter, L. (2010). The ASEAN Charter: ASEAN failure or member failure? International Law and Politics, 43, 159-210.

Marchini, P. L., Mazza, T., \& Medioli, A. (2018a). Related party transactions, corporate governance and earnings management. Corporate Governance: The International Journal of Business in Society, 18(6), 1124-1146. https://doi.org/10.1108/CG-112017-0271

Marchini, P. L., Mazza, T., \& Medioli, A. (2018b). The impact of related party transactions on earnings management: Some insights from the Italian context. Journal of Management and Governance, 1-34. https://doi.org/10.1007/s10997-0189415-y

North, G. (2009). A theoretical basis for selective disclosure regulation. University of New South Wales Law Journal, 32, 143. 
Pacces, A. M. (2011). How does corporate law matter? 'Law and Finance' and Beyond. In M. Faure \& J. Smits (Eds.), Does Law Matter on Law and Economic Growth. Intersentia.

Panda, B., \& Leepsa, N. M. (2017). Agency theory: Review of theory and evidence on problems and perspectives. Indian Journal of Corporate Governance, 10(1), 74-95. https://doi. org/10.1177/0974686217701467

Pistor, K., Keinan, Y., Kleinheisterkamp, J., \& West, M. D. (2003). Innovation in corporatelaw. Journal of Comparative Economics, 31, 676-694. https://doi.org/10.1016/j.jce.2003.09.004

Pizzo, M. (2013). Related party transactions under a contingency perspective. Journal of Management \& Governance, 17(2), 309-330. https://doi.org/10.1007/s10997-011-9178-1

Ramsay, I. M. (1998). Models of corporate governance regulation: The mandatory/enabling debate. In C. E. F. Rickett \& R. B. Grantham (Eds.), Corporate Personality in the 20th Century (pp. 215-270). Hart Publishing.

Ryngaert, M., \& Thomas, S. (2007). Related party transactions: Their origins and wealth effects. Retrieved from https://papers. ssrn.com/sol3/papers.cfm?abstract_id $=970689$

Salim, M. R. (2011). Corporate governance in Malaysia: The macro and micro issues. In C. A. Mallin (Ed.), Handbook on international corporate governance: Country analyses (pp. 269-294). Edward Elgar Publishing.

Salim, M. R. (2017). Malaysian Code on Corporate Governance 2017. Sweet \& Maxwell Asia.

Shin, I. H., Sohn, S. K., \& Park, S. (2019). Related party transactions and income smoothing: New evidence from Korea. AsiaPacific Journal of Accounting and Economics, 1-18. https:// doi.org/10.1080/16081625.2019.1566011

Notification of the Stock Exchange of Thailand: Opinion of Financial Advisors Concerning Connected Transaction, Pub. L. No. Bor.Jor./Por. 22-02 (2003). https://doi.org/10.1017/ CBO9781107415324.004

Utama, C. A., \& Utama, S. (2014). Corporate governance, size and disclosure of related party transactions, and firm value: Indonesia evidence. International Journal of Disclosure and Governance, 11(4), 341-365. https://doi.org/10.1057/ jdg.2013.23

Utama, S., Utama, C. A., \& Yuniasih, R. (2010). Related party transaction efficient or abusive: Indonesia evidence. Asia 
Pacific Journal of Accounting and Finance, 1(1), 77-102. http://apjaf.ui.ac.id/index.php/apjaf/article/view/8

Wan, W. Y. (2012). Independent financial advisers' opinions for public takeovers and related party transactions in Singapore. Company and Securities Law Journal, 30(1), 32-54.

Wan, W. Y. (2017). Cross-border public offering of securities in fostering an integrated ASEAN securities market: The experiences of Singapore, Malaysia and Thailand. Capital Markets Law Journal, 12(3), 381-411.

World Exchange Federation. (n.d.). Retrieved from https://statistics. world-exchanges.org/ 